\title{
Moisture content and water activity of arecanut samples: A need to revisit storage guidelines
}

\author{
K.B. Hebbar*, Sugatha Padmanabhan, S.V. Ramesh, S. Keshav Bhat ${ }^{1}$, P.P. Shameena \\ Beegum, R. Pandiselvam, M.R. Manikantan and A.C. Mathew \\ ICAR-Central Plantation Crops Research Institute, Kasaragod-671 124, Kerala, India \\ ${ }^{1}$ Arecanut Research and Development Foundation, Mangaluru-575 001, Karnataka, India
}

(Manuscript Received: 21-01-2021, Revised: 30-06-2021, Accepted: 02-07-2021)

Keywords: Arecanut, food standards, moisture content, storage, water activity

Arecanut (Areca catechu L.), also called betel nut, is an economically important palm species (Jaiswal et al., 2011). The palm is cultivated in most South Asian countries, including its major producers, India and China and other countries like Bangladesh, Japan, Malaysia, The Philippines, and Sri Lanka (Ramesh and Mohanraju, 2017). India is the largest producer of arecanut, accounting for 49.74 per cent of the world's output, and the crop is grown in an area of 4.95 lakh ha with a production of 8.09 lakh tonnes of the dry kernel (http:// www.fao.org/faostat/en/\#data/QC). The economically important component of the palm, the fruit, goes for chewing as "supari" owing to its stimulant effects and a minor fraction of the production for other commercial purposes. Thus, the edible endosperm is widely used as a masticatory in India and South East Asia, either alone or as a constituent of the quid along with betel leaves, lime and tobacco. Depending upon the nature of end products, the fruit is harvested at different stages of maturity for processing. The most popular traded form of arecanut is the whole dried nut known as chali or kottapak. The fruit of the palm is dried under direct sunlight for around three weeks or even more to reduce the moisture content to around 12-15 per cent (d.b.) (Kulanthaisami et al., 2007; Kalamullah and Gunasekar, 2002). Subsequently, they are stored in gunny bags or wooden boxes as whole nuts or dehusked nuts until they are sold (Mathew et al.,
1963). They are available in different grades like new rashi, old rashi, supari, patora, ulligadde etc. Another important form of traded arecanut is processed semi-mature varieties (such as bette, choor, rashi, and saraku), also known as red type, wherein tender nuts of 6-7 months maturity are dehusked, cut into pieces, boiled with water or diluted extract from a previous boiling, followed by tannin coating and drying. The number of cuts and dimensions of the cut pieces is categorized into api, bette, hasa, gorabulu etc. Dried nuts of both chali and red type are stored for marketing. Improper storage leads to spoilage of nuts and reduction in the market value rendering it unsuitable as a masticatory (Koti and Nambiar, 1979). One-yearold nuts during storage showed a significant decline in protein, fat, phenols, sugars and arecoline content (Chempakam and Saraswathy, 1985).

Moisture content (MC) of agricultural produce is an important physiological factor as it has an inverse relationship with the storage period. The high MC (>14\% w.b.) during the storage increases the respiration rate of agricultural products, resulting in mould/fungus infection (Aspergillus spp., which produces aflatoxins) and insect infestation. Further discolouration (due to heat buildup) and a severe loss in the fresh odour and sensory characteristics of products were observed. Further, the rate of physiological and biochemical changes in products

*Corresponding Author: hebbar.kb@icar.gov.in 
aggravates with an increase in MC. Water activity $\left(a_{w}\right)$, a measure of the energy status of water, is defined as a ratio of the vapour pressure of water in a sample to the vapour pressure of pure water at identical temperature and environmental conditions. A decrease in $\mathrm{a}_{\mathrm{w}}$ level below 0.7 prevents the spoilage caused by microorganisms (Labuza et al., 1972). To extend the storage life of food and agricultural products, the water activity has to be in a lower range where the deterioration rate is minimised (Ayub et al., 2003).

In arecanut, studies on the moisture content of processed nuts are scarce, and there are hardly any reports on the water activity of arecanuts. The permissible and critical limits of MC fixed for dried mature nut chali (13.1 and $15.2 \%$, respectively) and processed tender nut (11.0 and 12.32 per cent, respectively) seemed to be very high to prevent it from deterioration (Shivashankar and Govindarajan, 1963; Viraktamath 1963; Nambiar and Radhakrishnan Nair, 1970). On the other hand, the maximum standard moisture level of 7 per cent fixed by the Food Safety and Standards Authority of India (FSSAI) is too low to attain by the farmers (https:/ /www.thehindu.com/news/cities/Mangalore/re-fixstandard-moisture-level-in-arecanut-to-14stakeholders/article31035233.ece). Therefore, there is a need to optimise the moisture content of processed arecanut for its safe storage and ideal for mastication. In this context, the goal of the present study was to analyse the $\mathrm{MC}$ and $\mathrm{a}_{\mathrm{w}}$ of arecanut samples (red and chali) collected from different parts of arecanut growing regions of Karnataka, India and to identify suitable moisture content and water activity parameters so that it could be recommended for compliance by farmer growers and merchants during storage.

Arecanut samples were sourced from different places of Karnataka during dry and rainy seasons, including tender processed (red) and mature dried chali and their subtypes. Subtypes under red included api (4), bette (17), rashi (4), hasa (10), gorabalu (4). On the other hand, white 1 (4), new rashi (3), old rashi (3) patora (3) and ulligadde (1) are included under chali. A total of 53 samples were collected for the analysis. The samples ( $\sim 250 \mathrm{~g}$ nuts) were drawn from collection centres of 'The Malnad Areca Marketing Co-operative Society (MAMCOS)' of Koppa, Shringeri, Bhadravathi, Hosnagara, Shivamogga, and Thirthahalli located in Karnataka, India, and private vendors and farmers from Sirsi, Sagar, and Shivamogga. These samples were placed in sealed polythene bags for further analysis.

Prior to the analysis, the arecanut samples were broken into pieces using a supari cutter and ground

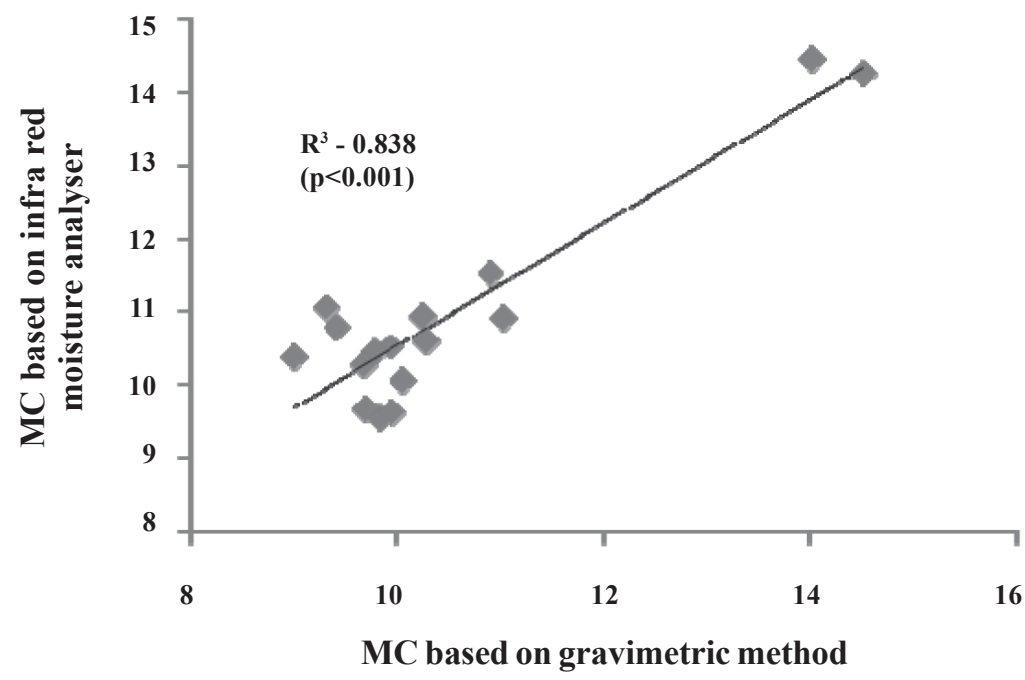

Fig. 1. Relationship between moisture content (MC) of arecanut samples (n=16) measured by gravimetric method and using infrared moisture metre 
into a fine powder using a laboratory blender. MC of the samples was estimated using moisture analyser A\&D MX-50 (Oxfordshire, UK). In few samples $(n=16)$, the MC of the arecanut samples were further estimated using a gravimetric method to calibrate the infrared moisture analyser for arecanut samples. The $\mathrm{a}_{\mathrm{w}}$ of the samples were measured using Novasina-Lab Master-aw: bench top metre (Novasina AG Neuheimstrasse $12 \mathrm{CH}$ 8853 Lachen). Each experiment was conducted in three replications. The data were analysed using one way ANOVA, and the treatment means were compared by Duncan multiple range test. The single factor ANOVA and MC and $\mathrm{a}_{\mathrm{w}}$ frequency distribution pattern were analysed using SAS software.

Table 1. Water activity $\left(a_{w}\right)$ and moisture content (MC) of arecanut samples collected from different places of Karnataka, India

\begin{tabular}{|c|c|c|c|}
\hline Sample & Types and sub types & Water activity $\left(a_{w}\right)$ & Moisture content $(\%)$ \\
\hline Across all samples $(n=159)$ & & 0.689 & 10.21 \\
\hline \multirow[t]{3}{*}{ Type } & Red (n=117) & 0.689 & 10.16 \\
\hline & $\operatorname{chali}(\mathrm{n}=42)$ & 0.676 & 9.54 \\
\hline & SEm & 0.013 & 0.62 \\
\hline \multirow[t]{6}{*}{ Sub types: Red } & Api & 0.696 & 10.43 \\
\hline & Bette & 0.682 & 9.96 \\
\hline & Rashi & 0.705 & 11.22 \\
\hline & Hasa & 0.689 & 10.21 \\
\hline & Gorabalu & 0.695 & 9.69 \\
\hline & SEm & NS & NS \\
\hline \multirow[t]{6}{*}{ Chali } & White 1 & $0.658^{b}$ & $9.07^{b}$ \\
\hline & New Rashi & $0.679^{b}$ & $9.43^{\mathrm{b}}$ \\
\hline & Old Rashi & $0.690^{\mathrm{ab}}$ & $10.08^{a b}$ \\
\hline & Patora & $0.666^{\mathrm{b}}$ & $9.22 \mathrm{~b}$ \\
\hline & Ulligadde & $0.727^{a}$ & $11.11^{\mathrm{a}}$ \\
\hline & SEm & 0.039 & 1.32 \\
\hline \multirow[t]{3}{*}{ Collection season } & Summer & 0.670 & $9.09^{c}$ \\
\hline & Monsoon & 0.684 & $10.17^{b}$ \\
\hline & $\mathrm{SEm}$ & NS & 0.92 \\
\hline \multirow[t]{11}{*}{ Collection from different locations } & Shivamogga & 0.709 & 10.91 \\
\hline & Sagar & 0.701 & 10.48 \\
\hline & Koppa & 0.686 & 9.74 \\
\hline & Shringeri & 0.661 & 8.96 \\
\hline & Thirthahalli & 0.681 & 9.73 \\
\hline & Sirsi & 0.673 & 9.75 \\
\hline & Kumta & 0.707 & 10.26 \\
\hline & Thrissur & 0.686 & 9.6 \\
\hline & Puttur & 0.684 & 10.63 \\
\hline & Others & 0.691 & 10.32 \\
\hline & SEm & NS & NS \\
\hline
\end{tabular}

[There were totally 53 samples of which 39 are red [Api(4); Bette (17);Rashi (4); Hasa (10); Gorabalu (4)] and 14 are chali [White (4); New Rashi (3); Old Rashi (3); Patora (3); Ulligadde (1)] types. Data are mean value of three replicates. Analysis of variance was calculated across types (red and chali), sub types, summer and monsoon collections and collection from different locations. Mean with same superscript letter represents non significance while different letter represents significance. Significance level of each factor is indicated by $p$-values and standard error of mean (SEm)] 


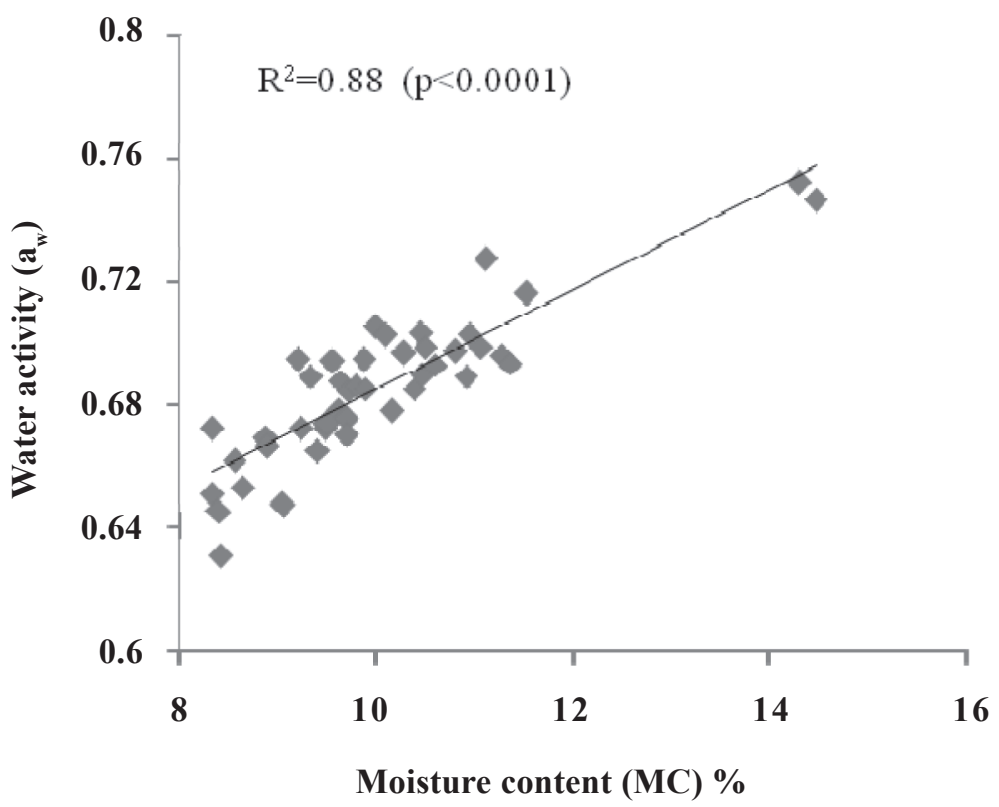

Fig. 2. Correlation between moisture content (\%) and water activity $\left(a_{w}\right)$ of arecanut samples $(n=53)$. Samples included dried red and chali and their sub types collected from different locations during summer and monsoon seasons

MC, determined by infra-red moisture analyser, had a strong positive correlation with the moisture content estimated by the gravimetric method $\left(\mathrm{R}^{2}(16)=0.84, \mathrm{p}<0.001\right)$ (Fig.1). It suggests that powdered arecanut samples could be directly measured for $\mathrm{MC}$ using an instant infra-red-based moisture analyser rather than following a relatively cumbersome and time-consuming gravimetric method. Hence, the arecanut growers and processing industries may use an infra-red-based moisture analyser to estimate the moisture content of different types of arecanut.

Table 2 depicts the $\mathrm{MC}$ and $\mathrm{a}_{\mathrm{w}}$ values across all the arecanut samples. The $\mathrm{MC}$ and $\mathrm{a}_{\mathrm{w}}$ values ranged from 8.33 to 14.46 per cent (w.b.) and 0.63 to 0.75 , with a mean of 10.21 per cent and 0.689 , respectively (Table 1). The red type arecanut samples had significantly high mean $\mathrm{MC}$ and $\mathrm{a}_{\mathrm{w}}$ (10.16\% and 0.689) compared to chali samples (9.54\% and 0.676). However, the MC values of both the types were lower than the earlier suggested permissible limits for chali (13.1\%) and processed tender nut (https://www.thehindu.com/news/cities/ Mangalore/re-fix-standard-moisture-level-in- arecanut-to-14-stakeholders/article31035233.ece). Analysis of MC and $\mathrm{a}_{\mathrm{w}}$ of various subtypes of red and chali arecanut samples revealed that there were no significant differences among the subtypes of red samples. Nevertheless, the subtypes of chali samples showed significant differences for $\mathrm{MC}$ and $\mathrm{a}_{\mathrm{w}}$ (p-value 0.05). Significantly high MC and $\mathrm{a}_{\mathrm{w}}$ were documented in ulligadde sub-samples followed by old rashi, whereas the least MC and $\mathrm{a}_{\mathrm{w}}$ was observed in white-I subsamples (Table 1). Expectedly, the samples collected during the rainy season (monsoon) had significantly $(\mathrm{p} \leq 0.01)$ more moisture $(10.17 \%)$ than the samples obtained during the summer season $(9.09 \%)$. However, there was no significant difference in their $\mathrm{a}_{\mathrm{w}}$. The MC (\%) and $a_{w}$ of the samples collected from different locations were analysed, and it was found that the place of the collection did not cause any significant change in both the parameters suggesting the robustness of this method for various agroecological zones of the country.

The frequency distribution charts of MC and $\mathrm{a}_{\mathrm{w}}$ of arecanut samples are depicted in Figure 3. It is apparent that 44.2 per cent ( 23 out of 52) of the 

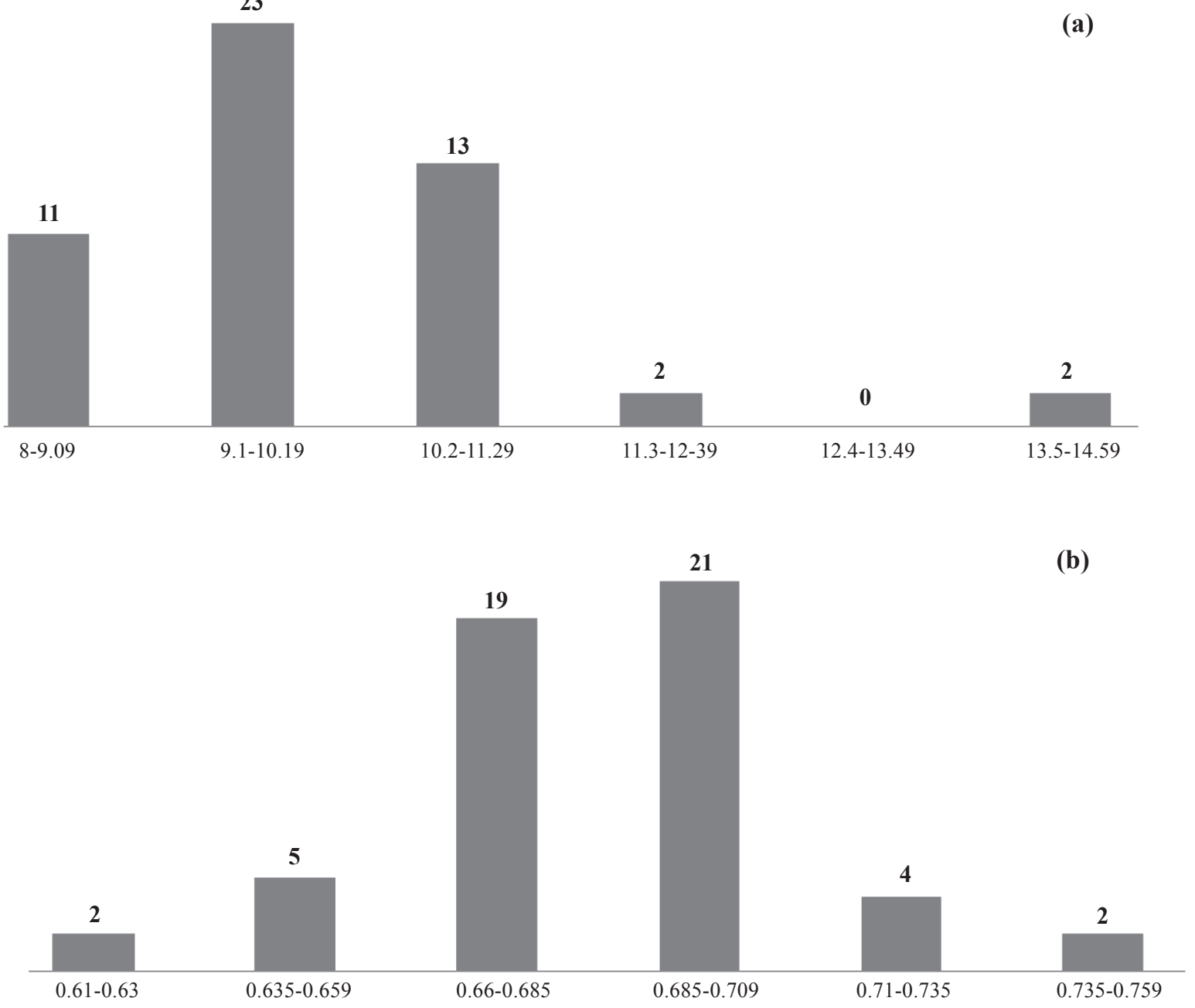

Fig. 3. Frequency distribution of (a) moisture content (MC) and (b) water activity $\left(a_{w}\right)$ of arecanut samples. $\mathrm{X}$-axis represents the frequency distribution class and the values above the bar indicate count against each class from $n=53$

samples recorded a $\mathrm{MC}$ of 9.1 to 10.19 per cent (w.b.). Whereas 40.4 per cent of samples exhibited $a_{w}$ of $0.685-0.709$ and 36.5 per cent samples recorded $\mathrm{a}_{\mathrm{w}}$ of $0.66-0.684$. Overall, more than 90 per cent of the samples recorded the $\mathrm{MC}$ and $\mathrm{a}_{\mathrm{w}}$ of $<11.3$ per cent and $<0.71$, respectively. The minimum $\mathrm{a}_{\mathrm{w}}$ required for the growth of bacteria and fungi is around 0.8 and 0.75 , respectively. Viraktamath (1963) reported the loss of flavour, crispness, development of stale odour and mould formation on nuts stored at a moisture content of 13-14 per cent while Nambiar and Radhakrishnan Nair (1970) observed an increase in fungal infection of nuts stored in jute bags from 16 to 32.3 per cent with an increase in moisture content from 9.5 to 15.6 per cent. Aspergillus flavus is the main fungi producing aflatoxin in arecanut. The fresh nuts having high $\mathrm{MC}$ are therefore easily contaminated with Aspergillus flavus. These studies indicated that Aspergillus flavus requires minimum water activity of 0.78 at $33{ }^{\circ} \mathrm{C}, 0.81$ at $30^{\circ} \mathrm{C}$ and 0.80 at $37^{\circ} \mathrm{C}$ (Pitt and Hocking, 2009). Astoreca et al. (2012) reported that the storage of corn at $<0.77$ water activity would be safe regardless of the storage temperature. As gunny bags are used to store the dehusked nuts, the fresh chali nuts are more 
susceptible to insect infestation and moulds or fungal infections with high moisture content (Thube et al., 2017).

In this study, arecanut samples sourced from different places during dry and rainy seasons, processed (red) and chali and their sub-types had a mean $\mathrm{a}_{\mathrm{w}}$ of $<0.71$ (corresponding moisture content of $<11.3 \%$ ), which is safe and unlikely to cause nut deterioration during storage. This study had not evaluated the plausibility of fungal or bacterial contamination and deterioration in other physical attributes depending on $\mathrm{a}_{\mathrm{w}}$. Nevertheless, prior investigations in various food products (BarbosaCánovas et al., 2003; Erkmen and Bozoglu, 2016, Asagbara et al., 2019) suggest that $\mathrm{a}_{\mathrm{w}}$ values $<0.71$ is safe. Therefore, mycotoxin accumulation and deterioration of quality of nuts seem improbable at $\mathrm{a}_{\mathrm{w}}$ values $<0.71$. Hence, the arecanut growers, processing industries and quality standard organization's like FSSAI must ensure $\mathrm{a}_{\mathrm{w}}$ of $<0.71$ for dried arecanut samples for its safe storage and mastication.

\section{References}

Asagbara, A.E., Onawola, O.O. and Okeagu, M.O., 2019. Identification of critical control points in some Nigerian fermented foods and seasonings. World Journal of Innovative Research 6(4): 55-60.

Astoreca, A., Vaamonde, G., Dalcero, A., Ramos, A. J. and Marín, S. 2012. Modelling the effect of temperature and water activity of Aspergillus flavus isolates from corn. International Journal of Food Microbiology 156(1): 60-67.

Ayub, M., Wahab, S. and Durrani, Y. 2003. Effect of water activity $\left(\mathrm{a}_{\mathrm{w}}\right)$, moisture content and total microbial count on the overall quality of bread. International Journal of Agriculture and Biology 5(3): 273-278.

Barbosa-Cánovas, G. V., Fernández-Molina, J. J., Alzamora, S. M., Tapia, M. S., López-Malo, A., and Chanes, J. W. 2003. Handling and Preservation of Fruits and Vegetables by Combined Methods for Rural Areas. Technical manual (No. 149). Food \& Agriculture Organization, Rome.

Chempakam, B. and Saraswathy, N. 1985. Biochemical changes during storage of arecanut (Areca catechu L.). In: Arecanut Research and Development. (Eds.): Bhat, K.S., Nair, C.P.R. Central Plantation Crops Research Institute, Kasaragod, 671124, India, pp. 163-166.

Erkmen, O. and Bozoglu, T.F., 2016. Food preservation by reducing water activity. In: Food Microbiology:
Principles into Practice. (Eds.) Erkmen, O. and Bozoglu, T.F., New York, NY: Wiley. pp. 44-58. doi:10.1002/ 9781119237860.ch30.

http://www.fao.org/faostat/en/\#data/QC.

https:/www.thehindu.com/news/cities/Mangalore/re-fixstandard-moisture-level-in-arecanut-to-14-stakeholders/ article31035233.ece.

Jaiswal, P., Kumar, P., Singh, V. K. and Singh, D. K. 2011. Areca catechu L.: A valuable herbal medicine against different health problems. Research Journal of Medicinal Plant 5(2): 145-152.

Kalamullah, S. and Gunasekar, J. J. 2002. Moisture-dependent physical properties of arecanut kernel. Biosystem Engineering Journal 82(3): 331-338.

Koti, R.M. and Nambiar, K.K.N. 1979. Fungal infection in stored arecanut. Journal of Plantation Crops 7: 50-53.

Kulanthaisami, S., Subramanian, P., Venkatachalam, P. and Sampathrajan, A., 2007. Drying kinetics of arecanut using solar-cum-biomass drying system. Madras Agricultural Journal 94(7-12): 256-268.

Labuza, T.P., Mc. Naly, L.D., Gallagher, J., Hawkes I., and Hurtado, F. 1972. The stability of intermediate moisture food. Journal of Food Science 37: 154.

Mathew, A.G., Venkataraman, S.D., Jaleel, S.A., Govindarajan, V.S., and Subramaniyan, V. 1963. Storage of arecanut fruit: 1- Preservative Steeping Storage. Arecanut Journal 14: 51-52.

Nambiar, K.K.N., and Radhakrishnan Nair, R. 1970. Spoilage of the processed arecanuts. Arecanut and Spices Bulletin 11: $8-10$.

Pitt, J. I., and Hocking, A. D. 2009. Aspergillus and related teleomorphs. In: Fungi and Food Spoilage. Springer, Boston, MA. https://doi.org/10.1007/978-0-387-92207-2 8. pp. 275-337.

Ramesh, C. H. and Mohanraju, R. 2017. Evaluation of antiluminous bacterial efficacy of Areca catechu nut methanol crude extraction in controlling luminous bacteria Vibrio campbellii in shrimp culture systems. Indian Journal of Geo-Marine Sciences 46: 2075-2080.

Shivashankar, S. and Govindarajan, V.S. 1963. Equilibrium relative humidity $(\mathrm{ERH})$ relationships of processed arecanut and whole dried ripe nuts. Food Science 12(11): 317-321.

Thube, S. H., Pandian, R. T. P., Bhavishya, E. K., Mohan, C. and Nagaraja, N. R. 2017. Major storage insect pests of arecanut Areca catechu L.- A Survey. Journal of Entomology and Zoology Studies 5(4): 1471-1475.

Viraktamath, C, S. (1963). Packing and storage studies on scented supari (Processed arecanut s). Food Science. 12: 322-325. 